\title{
苏南地区农村宅基地转型研究: 基于利用状态的视角
}

\author{
高金龙 ${ }^{1,2},{\text { 刘彦随 }{ }^{1}, \text { 陈江龙 }}^{2,3}$
}

(1. 中国科学院地理科学与资源研究所, 北京 $100101 ; 2$. 中国科学院流域地理学重点实验室, 中国科学院南 京地理与湖泊研究所, 南京 210008;3. 江苏省区域现代农业与环境保护协同创新中心, 淮安 223300)

\begin{abstract}
摘要：农村宅基地转型是土地利用转型研究的重要内容。目前学界关于宅基地转型的研究主 要集中在规模结构等显性形态方面,对隐性转型的研究仍较欠缺。以乡村经济发达的苏南地 区为例,通过对正常使用、空置、废弃等不同利用状态宅基地空间分异规律的刻画,探索其功能 转型的一般规律, 并进一步分析宅基地空置与废弃的影响因素。结果表明: 在乡村振兴战略实 施背景下, “房子不用来住” 的问题在农村地区同样存在, 而且在不同代际和空间区位上农村宅 基地的利用状态有所差异。具体地, 1980年以前的老宅基地从距离城镇较远和较近的“两端” 开始, 其空废比率向中间地带递减; 随着市场化和城镇化水平提升, 1980-2000年的中龄宅基 地空废比率呈现由近郊向外递减的趋势, 城镇化影响下的距离衰减规律明显。近年来, 伴随农 村宅基地财产/资产属性的逐步显现,农村宅基地的利用状态与空间区位之间的关联关系弱 化。2010年以后新宅基地的空置率出现反弹, 尤其靠近城镇的农村地区“囤地”现象严重, 发端 于城镇地区的“地产霸权”正在向乡村地区蔓延。
\end{abstract}

关键词: 土地利用转型; 宅基地; 空置/废弃地; 乡村振兴;苏南

改革开放以来，中国的农村经济社会发展经历了剧烈的转型和重构，农村土地利用 出现了“农地高速非农化” “建设用地低效化” 和 “宅基地空心化” 等诸多问题，给乡村 地区的高质量可持续发展带来了严峻挑战 ${ }^{[1,2]}$ 。党的 “十九大” 审时度势, 创新地提出中 国特色社会主义进人新时代，强调 “实施乡村振兴战略”，着力破解城乡发展不平衡、农 村发展不充分等突出问题, 弥补全面建成小康社会的乡村短板 ${ }^{[3-5]}$ 。在乡村振兴战略实施 过程中，如何通过有效的土地管理制度创新，助力城乡融合发展，是亟待解决的现实问 题, 也是地理学研究面向国家战略需求的重要课题 ${ }^{[3,6,7]}$ 。

作为农村居民生产和生活的重要载体，宅基地为农民提供了最基本的住房保障，也 是中国城乡发展及土地利用转型的重要源头之一 ${ }^{[8-10]}$ 。近年, 关于宅基地转型的研究在国内 蓬勃开展，尤其在宅基地转型的理论假说及其与城乡发展关系等方面取得较好进展 ${ }^{[11-13]}$ 。 龙花楼等 ${ }^{[14]}$ 基于长江沿线样带分析发现，农村宅基地在新增城乡建设用地中的比例由下

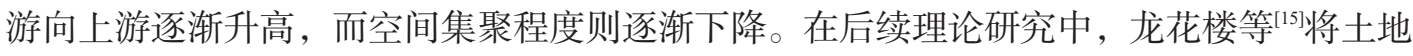
利用转型的概念由最初数量与结构的范畴, 拓展为显性与隐性两种形态的转变; 并强调 经济社会发展影响土地利用形态，土地利用形态又反过来作用于经济社会发展，二者相

收稿日期：2020-03-16；修订日期：2020-06-03

基金项目：国家自然科学基金项目（41971215，41771193，41571169); 江苏省国土资源科技项目（KJXM2017017）

作者简介：高金龙 (1988- ), 男, 山东无棣人, 博士, 副研究员, 研究方向为城乡发展与土地利用。

E-mail: jlgao@niglas.ac.cn

通讯作者：陈江龙 (1974- ), 男, 福建厦门人, 博士, 研究员, 博士生导师, 研究方向为国土空间规划与管理、城 乡发展与区域规划。E-mail: jlchen@niglas.ac.cn 
互作用与相互影响促成了土地利用转型 ${ }^{[1]}$ 。还有学者基于人地关系视角, 对宅基地转型 的空间结构及其与经济发展的关联性 ${ }^{[16]}$, 以及不同地区农村宅基地的合理规模进行了有 益探索 ${ }^{[17]}$ 。但是，受制于解释不同现象及其时空过程所需数据与方法的复杂性 ${ }^{[11,18]}$, 目前 对宅基地转型的定量研究仍以显性形态分析为主，对隐性转型的探讨仍局限于理论层面。

理论上, 宅基地的隐性转型可以理解为宅基地由传统的居住向其他非居住功能的转 变, 这种转变通常伴随宅基地利用状态和效率的变化 ${ }^{[19,20]}$ 。尤其是发达地区的乡村已不像 传统乡村聚落一样，仅作为农民生产生活的场所，同时还兼具了生态和休闲等多种功 能，宅基地也由原来单一的居住功能衍生出其他生产性或财产性功能，作为居住空间的宅 基地空置和废弃现象时有发生 ${ }^{[21-23]}$ 。所以说，宅基地的利用状态能在一定程度上反映区域 土地利用的功能转型特征，对于认识耦合的 “土地系统” 可起到窥斑见豹的作用 ${ }^{[13,24]}$ 。本 文即以乡村经济发达的苏南地区为例, 试图从农村宅基地利用状态的视角, 对其功能转 型特征进行探索, 以期能够抛砖引玉，引起更多学者对这一问题的关注，进而对现有研 究范畴进行补充。

\section{1 理论假设}

\section{1 农村宅基地转型的历史趋势}

1949年新中国成立之初，严格的城乡二元户籍制度把广大农民禁锢在农村，规模庞 大的农村人口对应巨大的宅基地规模 ${ }^{[25]}$ 。计划经济时期，农村集体经济在一定程度上抑 制了农民发展生产的积极性，较低的经济收人难以满足多样化的住房需求; 加之 “割资 本主义尾巴” 思潮的风靡，农村居民改善居住条件的正常需求受到限制，取而代之的是 宅基地使用权的代际继承与传递 ${ }^{[1]}$ 。这一时期宅基地的主要功能是满足农民最基本的居 住需求，宅基地空置或废弃现象极为鲜见。

改革开放以后，伴随家庭联产承包责任制的实行，越来越多的劳动力从农业生产中 释放出来; 加之乡镇企业雨后春笋般地发展, 农村剩余劳动力在城乡之间的流动成为可 能 ${ }^{[25-29]}$ 。多样化的经济活动提高了居民家庭收人水平, 对舒适宽敞住宅的需求也得到释 放，农村迎来住房建设高潮，宅基地供给不断增加 ${ }^{[1,30,31]}$ 。在快速工业化进程下，靠近城 镇的地区率先出现劳动力的 “城乡双栖” 现象，农村住宅原本的居住功能被削弱，宅基 地的利用效率有所下降，空置现象开始出现，但宅基地的废弃仍不多见。

随着城镇化进程加速，农村人口加速外流，固于农村土地产权制度的固有缺陷和城 乡社会保障制度的差异，纵使土地使用权人已进城定居，仍有相当部分的宅基地无法正 常退出 ${ }^{[25,32,33]}$ 。此外，伴随农村经济快速发展和农民收人水平提高，宅基地空间布局也发 生重大变化，尤其 “一户多宅” 等带来的建设用地 “外扩内空” 现象日益严重 ${ }^{[3]}$ 。对于 “城乡双栖” 的进城务工人员，宅基地除最基本的居住功能外，还具有一定的福利保障与 资产功能。随着新时代乡村振兴战略的实施, 在未来一段时间内势必会有大量人口返乡 创业兴业, 可能会带来新一轮的建房高潮, 也可能会有越来越多的空废土地会通过存量 挖潜的形式被再次开发, 具体的转型方向还有赖于新时代背景下的制度走向和城乡融合 发展水平 (图 1)。

\section{2 农村宅基地转型的空间假设}

乡村作为中国现代化的 “稳定器” 和 “蓄水池”, 是国家城镇化建设的重要支撑 ${ }^{[3]}$ 。 
如前所述, 农村宅基地同时承担居住 和福利保障功能, 既要为驻村居民提 供居住服务, 还要为进城农民提供必 要的社会福利保障。实践中, 宅基地 的利用状态可间接表征不同功能的转 化特征, 正常使用的宅基地主要发挥 居住功能, 而空置或废弃则表示居住 功能退化, 主要发挥福利保障功能。 一般而言, 在城镇化水平较低的地区 或发展阶段, 城乡差距较大, 劳动力



图 1 农村宅基地转型趋势的理论假设

Fig. 1 Theoretical hypothesis on rural housing land transition trend 和生产资料均呈现 “向城集聚” 趋势 ${ }^{[36]}$ 。一方面, 宅基地规模随着到城镇距离增加而减 少, 当达到一定距离衰减趋势减弱, 甚至在远离城镇地区呈现出相对均衡的随机分布格 局; 另一方面, 受城镇化辐射影响, 宅基地利用状态呈现梯度变化, 即越靠近城镇宅基 地区位特征越明显, 利用价值越高, 空废比率越小, 而偏远乡村地区宅基地价值较低, 空废率越高（图 2a）。
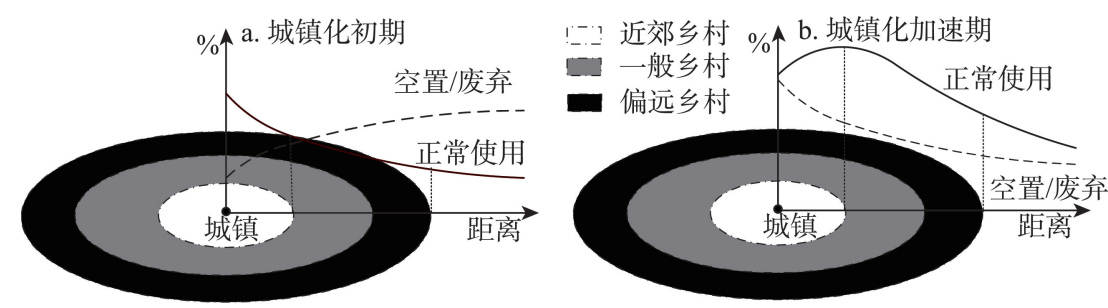

图 2 农村宅基地转型的理论模型

Fig. 2 Theoretical models of rural housing land transition

对于城镇化水平较高的地区, 城乡差异较小, 城镇化地区对人口及生产资料的虹吸 作用也相对较小，在靠近城镇地区反而会出现用地规模先增加后减少的倒 “U” 型格局 （图 2b）。也即随着城镇化进人加速阶段，宅基地原本的居住功能会随着城乡融合程度的 深人而被弱化, 资产属性伴随城乡要素流动而日益凸显, 尤其越靠近城镇的乡村空间越 容易受城镇化影响, 宅基地被资本化（征收拆迁）的概率也相应增加，反而在一定距离 之外土地利用效率最高, 继续向外则又重新呈现出一般意义上的距离衰减。从宅基地使 用权人的角度，靠近城镇的地区进城发展机会较多，宅基地转型的机会成本相对较低， 再加之随时可能发生的城镇化占用，导致越靠近城镇地区的宅基空置/废弃比率越高 ${ }^{[37]}$; 在远离城镇的偏远农区, 受到交通区位等条件限制, 农村发展基础薄弱、农民收人水平 较低, 宅基地转型可获得的潜在收益 (级差收益) 相对较高 ${ }^{[38]}$ 。总之, 在 “低成本” 和 “高收益” 的双重驱动下, 宅基地的功能转型通常始于距离城镇较远和较近的 “两端”, 而位于城乡连续体（urban-rural continuum）中间地带的宅基地转型的进程反而较慢。

\section{2 研究方法与数据来源}

\section{1 研究区概况与数据来源}

研究区国土面积 2.8 万 $\mathrm{km}^{2}$ ，是我国人口和经济密度最高的区域之一，也是 “苏南 
模式” 发源地（图 3); 城镇化、工 业化与乡村发展交互影响, 是开展 乡村地理相关理论研究的极佳试验 地 ${ }^{[29,39-42]}$ 。2016 年, 苏南五市常住人 口逾 3300 万, 乡村人口占比超过 $20 \%$; 登记农村家庭 340.91 万户， 占全省近四分之一; 农村家庭人均 可支配收人 24638 元, 高出全国平 均水平一倍。

本文采用的数据主要基于 2016 年江苏省农村建设用地调查。 首先提取苏南五市农村宅基地的宗 地图斑，按照国土安全及政府管理

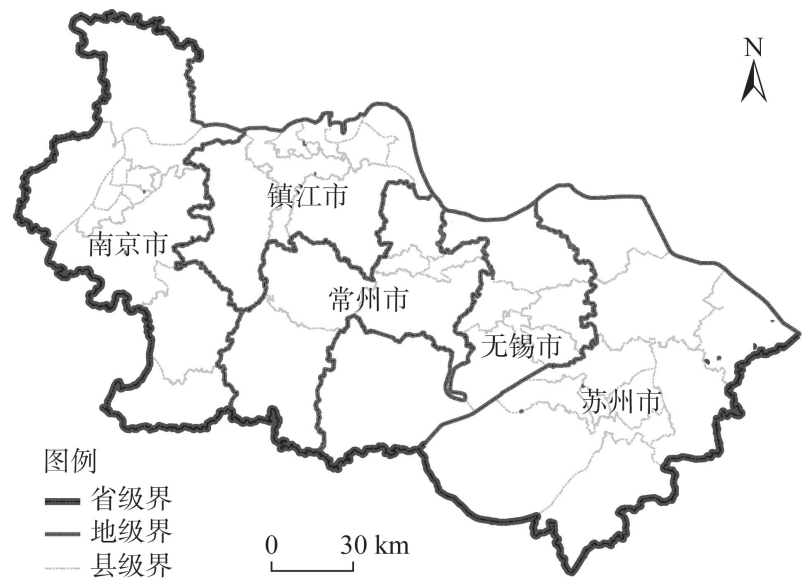

图 3 研究区位置与组成示意图

Fig. 3 Location and spatial organization of Southern Jiangsu 的要求, 进行 “面转点 (几何中

心）”的脱敏处理，并采用核密度估计方法进行非直接空间表征。脱敏后的点数据保留 宅基地基本情况、利用状态和使用权人信息等。其中，宅基地基本情况包括宗地面积、 建（构）筑面积、建造时间、建（构）筑类型和层数等信息，宅基地利用状态分为正常 使用、空置和废弃三种（空置是指房屋保存完好、连续两年居住天数不足一个月的宅基 地，废弃是指有房屋但无法居住的宅基地），使用权人基本情况包括户籍人数、常住人 口、农户类型和处置意愿等。

\section{2 研究方法}

本文研究目的在于揭示发达地区农村宅基地功能转型的一般规律, 因此研究方法也 以格局刻画和现象描述为主，主要包括缓冲区分析、核密度估计及调查统计。其中，缓 冲区分析（Buffer Analysis）是以苏南地区主要城市的中心 ${ }^{\mathbb{1}}$ 为原点构建 $1 \mathrm{~km}$ 的缓冲区, 并与脱敏后的农村宅基地数据进行叠置，耦合宅基地的利用状态与其空间距离信息，监 测农村宅基地功能转型的空间分异规律。

核密度估计（Kernel Density Estimation）通过考察农村宅基地的点密度空间变化来 刻画其空间分布特征。该方法认为地理事件可以发生在空间的任何位置上，但是不同位 置上事件发生的概率是不同的，一般说来，点密集的区域事件发生的概率高，点稀疏的 区域事件发生的概率低。一般通过测度研究区域中单位面积上事件数来估计点 $p$ 的密度 为 $\lambda_{h}(p)$ ，其估计值为 $\hat{\lambda}_{h}(p)$ ，则:

$$
\hat{\lambda}_{h}(p)=\sum_{i=1}^{n} \frac{1}{h^{2}} k\left(\frac{p-p_{i}}{h}\right)
$$

式中： $k(\cdot)$ 为核函数；假设农村宅基地的点集为 $\left\{p_{1}, \cdots, p_{n}\right\} ; p$ 为待估计点的位置； $p_{i}$ 为 落在以 $p$ 为圆心、以 $h$ 为半径的圆形范围内的第 $i$ 个宅基地的位置，代表带宽，即以 $p$ 为 源点的曲面在空间上延展的宽度， $h$ 值的选择影响分布密度估计的平滑程度，在具体应 用中, $h$ 的取值有弹性。

(1) 南京市新街口、无锡市三阳广场、常州市南大街、苏州市观前街、镇江市大市口，其他县市中心以本级人民 政府所在地为准。 


\section{3 结果分析}

\section{1 农村宅基地转型的时空分异}

\section{1 .1 空间分异}

根据调查数据，苏南地区现有农村宅基地 312 万宗，总面积约 $63786 \mathrm{hm}^{2}$ ，占全部调 查农村建设用地总规模的 $20.42 \%$ 。如图 4所示，正常使用面积 $57070 \mathrm{hm}^{2}$ ，空置和废弃分 别有 $5820 \mathrm{hm}^{2}$ 和 $892 \mathrm{hm}^{2}$, 空废比例高达 $10.53 \%$ 。具体地，在城镇中心 $5 \mathrm{~km}$ 辐射范围内 的宅基地有 $2141 \mathrm{hm}^{2}$ ，其中正常使用、空置和废弃的比例分别为 $84 \%$ 、 $12 \%$ 和 4\% ; 而在 外围乡村地区，正常使用面积占比呈现波动上升趋势，并在远离城镇的 $30 \mathrm{~km}$ 以外地区 达到相对稳定的水平；在同样的空间梯度上，空置和废弃比例则分别呈现出 “持续降 低”和“先降后升”的态势。

究其原因，一方面在城镇化进程中农村宅基地的资产属性需要通过货币化的形式表 征，而越靠近城镇地区的农村宅基地价值实现的可能性越大，“空置待拆” 的处置方式成 为宅基地使用权人的理性选择，导致这些区域宅基地的正常使用比率相对较低，加速了 近郊区宅基地由“居住空间”向 “家庭资产” 的功能转型 ${ }^{[9,43]}$; 另一方 面, 乡村发展受城镇化影响随着距 离的增加递减, 到城镇距离达到一 定阈值后，农村宅基地的正常使用 率趋于稳定, 而且随着居民“两 栖”成本的增加，偏远地区农村宅基 地所有权人更倾向于进城定居，从而 导致宅基地废弃比例攀升而空置比例 较低 ${ }^{[27]}$ 。

为更直观地刻画农村宅基地利 用状态的空间分异特征，对三种状 态下的宅基地分布进行核密度估 计。如图 5 所示, 正常使用宅基地主 要集中交通相对便捷但到城镇有一 定距离的地区，如苏州张家港、常 熟、太仓的沿江地区，以及镇江扬 中和南京六合、江宁等沿江地区; 空置宅基地则大多集中在城市近郊 区, 到城镇距离较正常使用宅基地 更近，如江宁、句容、丹阳、溧 阳、武进、惠山、相城等城市副中 心（或县城区）的周边；废弃宅基 地则主要集中在相对偏远的乡村地 区，尤其到中心城市距离普遍较远。
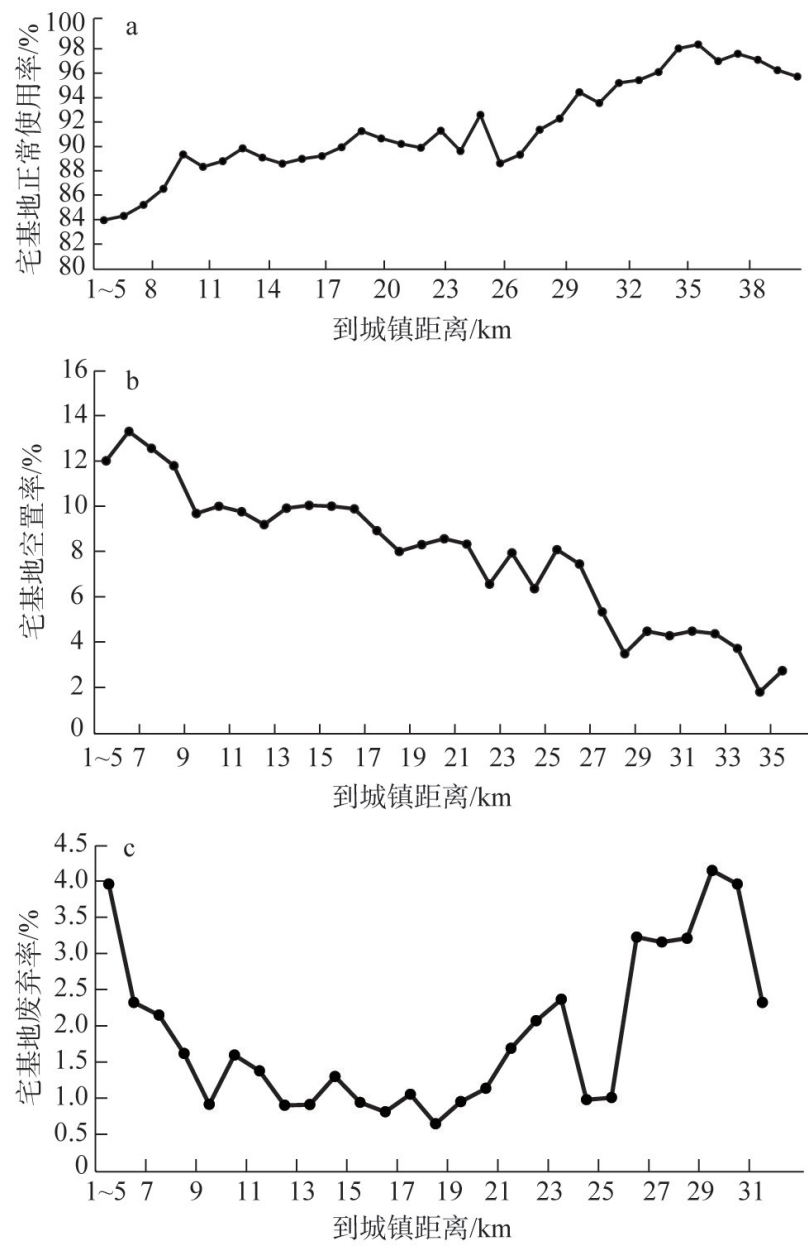

图 4 苏南地区农村宅基地空间距离衰减

Fig. 4 Distance-decay of rural housing land in Southern Jiangsu 

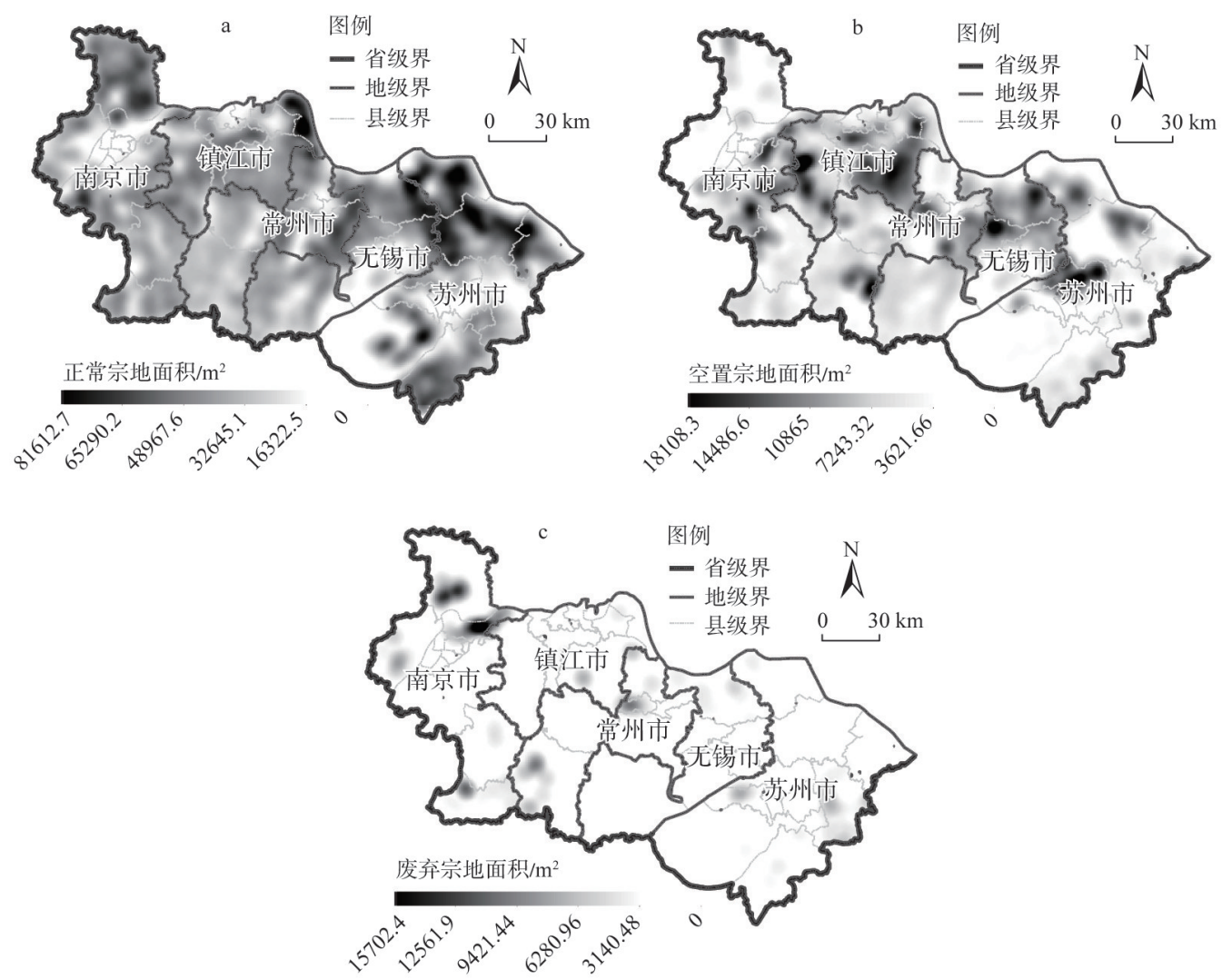

图 5 苏南地区农村宅基地核密度估计

Fig. 5 Kernel density of rural housing land in Southern Jiangsu

\section{1 .2 代际演替}

一般而言，假定农村居民每 20 年（子女适婚年龄）进行一次住房建设（新建或翻 建), 据此可将农村宅基地按建筑年代划分为三种代际类型，即建设时间在 1980 年以前 的定义为老宅基地、1980-1999年之间的为中龄宅基地、2000年以后的为新宅基地。其 中，老宅基地的使用主体通常是 55 岁及以上（1960年以前出生）的中老年人，空置和废 弃比例分别为 14.98\% 和 $2.47 \%$; 中龄宅基地的使用主体以 35 55 岁（1960-1980 年出 生）的中年人为主，空置和废弃比例分别为 $7.18 \%$ 和 $1.46 \%$; 新宅基地的使用主体则多为 35 岁以下（1980年以后出生）的青年人, 空置和废弃比例 $6.69 \%$ 和 $0.91 \%$ 。可见, 建设 年代越久远的宅基地空废比例越高，这与苏南地区普遍存在的农村宅基地 “建新不拆 旧” 有关 ${ }^{[14,32]}$ 。空间上, 宅基地的空废率随着到城镇距离的增加呈现一定递变规律, 并表 现出较明显的代际差异（图 6)。其中，老宅基地的空置与废弃比例呈现出近似 “先减后 增” 的 “U” 型趋势, 即在靠近和远离城镇的地区空置和废弃比例最高; 中龄宅基地的 空置和废弃比率则一直保持较为稳定的递减趋势，而新宅基地的递变规律最不明显。

改革开放前城乡发展差距较大，近郊农村居民更容易获得城镇发展的机会（成本 低)，而偏远地区农村居民进城发展的级差收益更大（收益高，因此老宅基地空废率呈 “U” 型。随着市场经济制度的引人，农村居民收人明显提高，城乡差异也逐渐缩小，农 村宅基地的空置和废弃比例随着建筑面积及风格的改进而降低 ${ }^{[11,12]}$, 尤其在偏远地区空废 


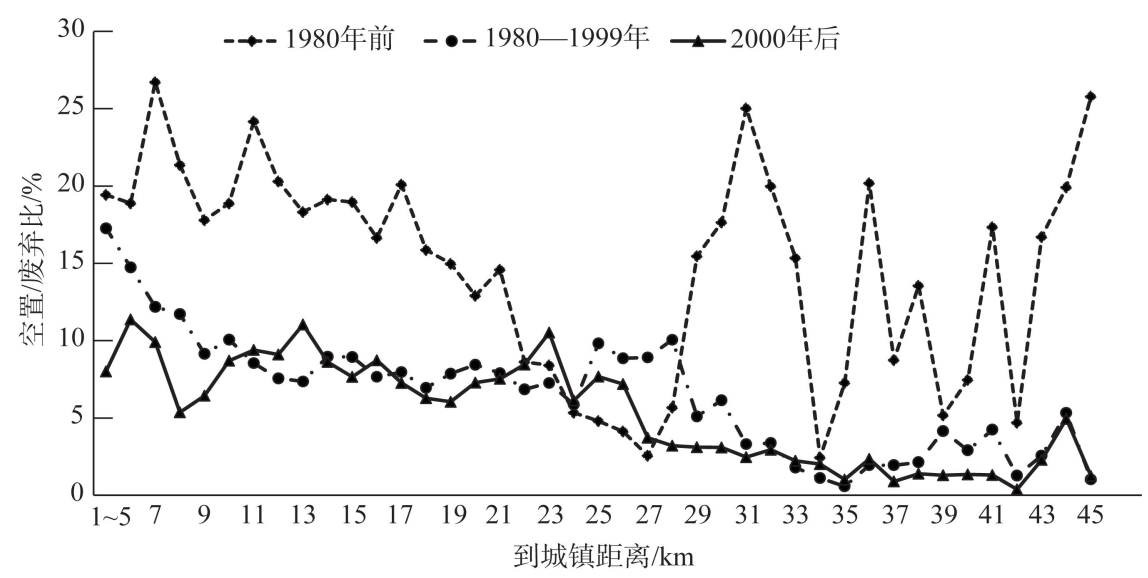

图6 苏南地区农村宅基地利用状态的代际演替

Fig. 6 Intergenerational difference of rural housing land in terms of statues in Southern Jiangsu

率下降明显; 而在快速城镇化进程的影响下，近郊农村宅基地仍表现为较高的空废比 率，中龄宅基地的整体距离衰减规律明显。对于新宅基地而言，在较高市场化和城镇化 水平下，除最基本的居住功能外，其特有的资产属性也被逐渐挖掘，因此正常使用的比 例明显提升，距离衰减规律也有所弱化。但是从更细的时间尺度划分，2010年之后的新 宅基地空置率较之前年份有明显上升，而废弃率则保持较低水平（表 1)，表明近年来的 农村地区部分新建住宅并非出于居住的刚性需求，而更可能是农村宅基地由 “居住空 间” 向 “家庭资产” 的功能转型所致 ${ }^{[32,44]}$ 。

\section{2 农村宅基地空废的影响因素}

如表 1 所示，空置宅基地的平均面积和建筑面积明显小于正常使用状态，可以推断

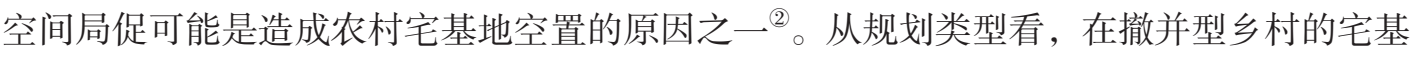
地空置和废弃比例高达三分之一，明显高于保留型和集聚型乡村，表明地方政府对乡村 发展的规划引导也能够在一定程度上影响宅基地的转型进程; 同时需要关注的是, 在撤 并型乡村仍有 $66 \%$ 的宅基地属于正常使用，涉及农户超过 15 万，需要在未来乡村撤并和 土地综合整治中逐步安置。从家庭生计来源看, 随着对农业经济部门依赖程度的降低, 纯农户、兼业户、非农户的宅基地空置和废弃比例依次增加。

从建筑属性看，建筑时间与宅基地利用状态之间存在近似倒“U”型的线性关系， 即建筑时间最早（1980 年以前）和最晚（2010年以后）的宅基地空置或废弃的比例最 高，而中间年份（1980-2009年）的农村宅基地正常使用比例最高，印证了上述宅基地 转型的代际演替规律。除此之外, 房屋建筑结构对宅基地的利用状态也有很大相关性, 钢混结构建筑的正常使用比例最高, 其他依次为砖混、砖木和其他结构, 这一特征可从 建筑造价和房屋安全性等方面进行解释。

\section{2 .1 空置原因}

除政府规划引导、农户家庭类型和建筑属性等环境及家庭要素外，农村宅基地的利 用状态更直接受个体行为的影响。由于中国农村社会环境的特殊性，相当部分的农村居

(2) 据负责农村建设用地调查的技术人员介绍, 对农村废弃建设用地的调查并未按照严格的宗地边界测算, 而是 将相邻宗地进行归并处理，因而其平均宗地面积和建筑面积均大于正常使用和空置用地。 
表 1 不同利用状态农村宅基地特征比较

Table 1 Characteristics of rural housing lands under different states of utilization

\begin{tabular}{|c|c|c|c|c|}
\hline \multicolumn{2}{|c|}{ 利用状态 } & 正常使用 & 空置 & 废弃 \\
\hline \multicolumn{2}{|c|}{ 平均宗地面积 $/ \mathrm{m}^{2}$} & 208 & 160 & 405 \\
\hline \multicolumn{2}{|c|}{ 平均建筑物面积 $/ \mathrm{m}^{2}$} & 228 & 175 & 366 \\
\hline \multicolumn{2}{|c|}{ 平均户籍人口数/人 } & 3.45 & 1.41 & 1.18 \\
\hline \multirow[t]{3}{*}{ 规划类型"/\% } & 撤并型 & 66.13 & 31.02 & 2.85 \\
\hline & 保留型 & 89.26 & 9.96 & 0.78 \\
\hline & 集聚型 & 86.63 & 12.63 & 0.74 \\
\hline \multirow[t]{3}{*}{ 农户类型"**\% } & 纯农户 & 93.11 & 6.24 & 0.65 \\
\hline & 兼业农户 & 82.89 & 16.42 & 0.69 \\
\hline & 非农户 & 77.15 & 21.77 & 1.08 \\
\hline \multirow[t]{5}{*}{ 建构时间/\% } & 1980 年前 & 76.63 & 22.15 & 1.22 \\
\hline & 1980-1989年 & 91.96 & 7.66 & 0.38 \\
\hline & 1990-1999年 & 90.18 & 8.73 & 1.08 \\
\hline & 2000-2009年 & 93.27 & 6.43 & 0.31 \\
\hline & 2010年后 & 87.40 & 12.33 & 0.26 \\
\hline \multirow[t]{4}{*}{ 建筑类型/\% } & 砖混 & 90.73 & 8.37 & 0.90 \\
\hline & 钢混 & 92.19 & 7.37 & 0.44 \\
\hline & 砖木 & 84.47 & 15.14 & 0.39 \\
\hline & 其他 & 81.20 & 18.40 & 0.40 \\
\hline
\end{tabular}

注：“规划类型包括撤并、保留和集聚三种，分别指规划期间居住人口将持续流出、保持稳定和不断流入的区 域; “调查中有 9791 宗宅基地的农户类型属性为空，未纳人分析。

民参与土地调查的积极性不高，近六成的宅基地空置原因为 “其他” 或空白（统一标记 为 “其他” )。在剩余 147460 宗空置宅基地中有 18.0\%由 “迁走” 所致，其次为 “一户多 宅” 和 “常年在外” 分别占比 $13.7 \%$ 和 $10.9 \%$, 另有 $0.2 \%$ 的空置宅基地是产权人预留 “将来建房”（图 7)。

如图 8 所示，因产权人迁走而空置的农村宅基地主要集中在南京江宁、苏州相城和 常州武进等新市区, 这些地区正在经历剧烈的城镇化进程, 规模庞大的农民离乡进城, 进城人员对宅基地潜在收益具有一定预期，因此不会轻易放弃宅基地的使用权，导致大 量农村宅基地空置; 由于产权人常年在外而空置的农村宅基地分布相对分散，但也有围 绕主要县城及中心镇等非农就业中心集聚的态势; 因一户多宅而空置的农村宅基地主要 集中在区县交界地区，对农村宅基地的管理相对薄弱，而宅基地本身的市场价值也相对 较低; 为预留将来盖房而空置的农村宅基地与一户多宅分布类似，均属于农村发展相对 落后、产权人对 “将来是否回乡发展” 不明确、而政府管理又相对薄弱的地区。

进一步耦合李平星等 ${ }^{[45]}$ 对苏南地区重要生态功能保护区的研究发现，举家搬迁导致 的宅基地空置主要集中在水源地和重要水体、湿地等水源涵养区附近，表明生态保护是 苏南地区农村宅基地转型的重要考量; 常年在外导致的空置宅基地则多分布在宁镇丘陵 和宜溧山区，表明自然条件对农村经济社会发展及其土地利用状态的重要影响。相比之 下，一户多宅和将来建房类的空置宅基地则主要集中在自然地理条件相对优越的经济发 达地区。总之, 宅基地所呈现的不同利用状态应该是内部性要素和外部性要素综合作用 
的过程，除农户自身偏好和决策外，规划 政策和自然地理等外生变量同样具有重要 作用。

\section{2 .2 废弃原因}

由于对农村废弃宅基地调查通常面临 产权主体缺失的问题，信息获取难度更 大，本文中有约四分之三的农村宅基地废 弃原因不明。如图 9 所示, 在参与调查的 9554 宗废弃宅基地中，有 20\% 是由“迁 走” 所致，空间上以南京六合、溧水两区 的城关镇周边最为集中，江阴、太仓等城 区外围也有一定分布; 其次为 “另建新 宅” 占比 3.4\%, 空间上与因 “一户多宅” 而空置的宅基地相类似，主要分布在农村 集体组织薄弱且管理相对松散、乡村未来 发展方向不明确的交界地区; 另有 $1.8 \%$ 的

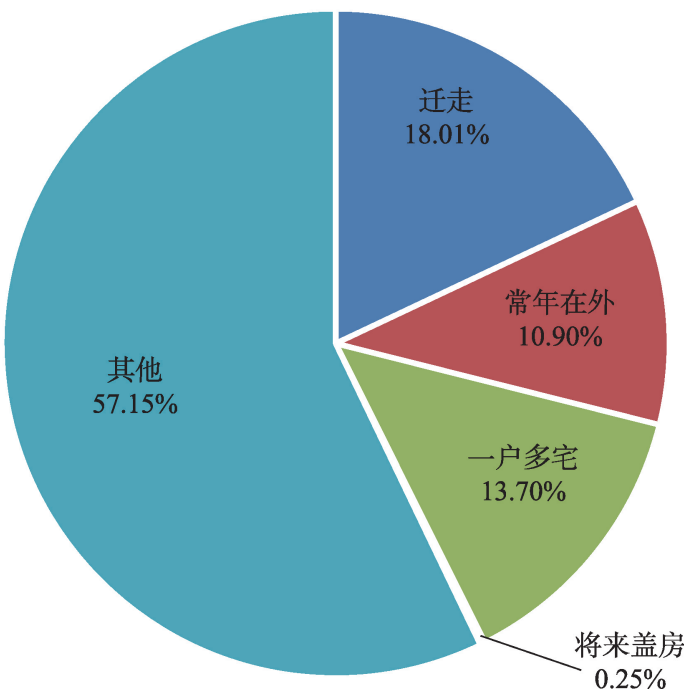

图 7 苏南地区农村样本宅基地空置原因

Fig. 7 Vacant reasons for sample rural housing land in Southern Jiangsu

废弃宅基地是由于原产权人去世后 “无人继承”，空间分布相对随机。空间上，宅基地废
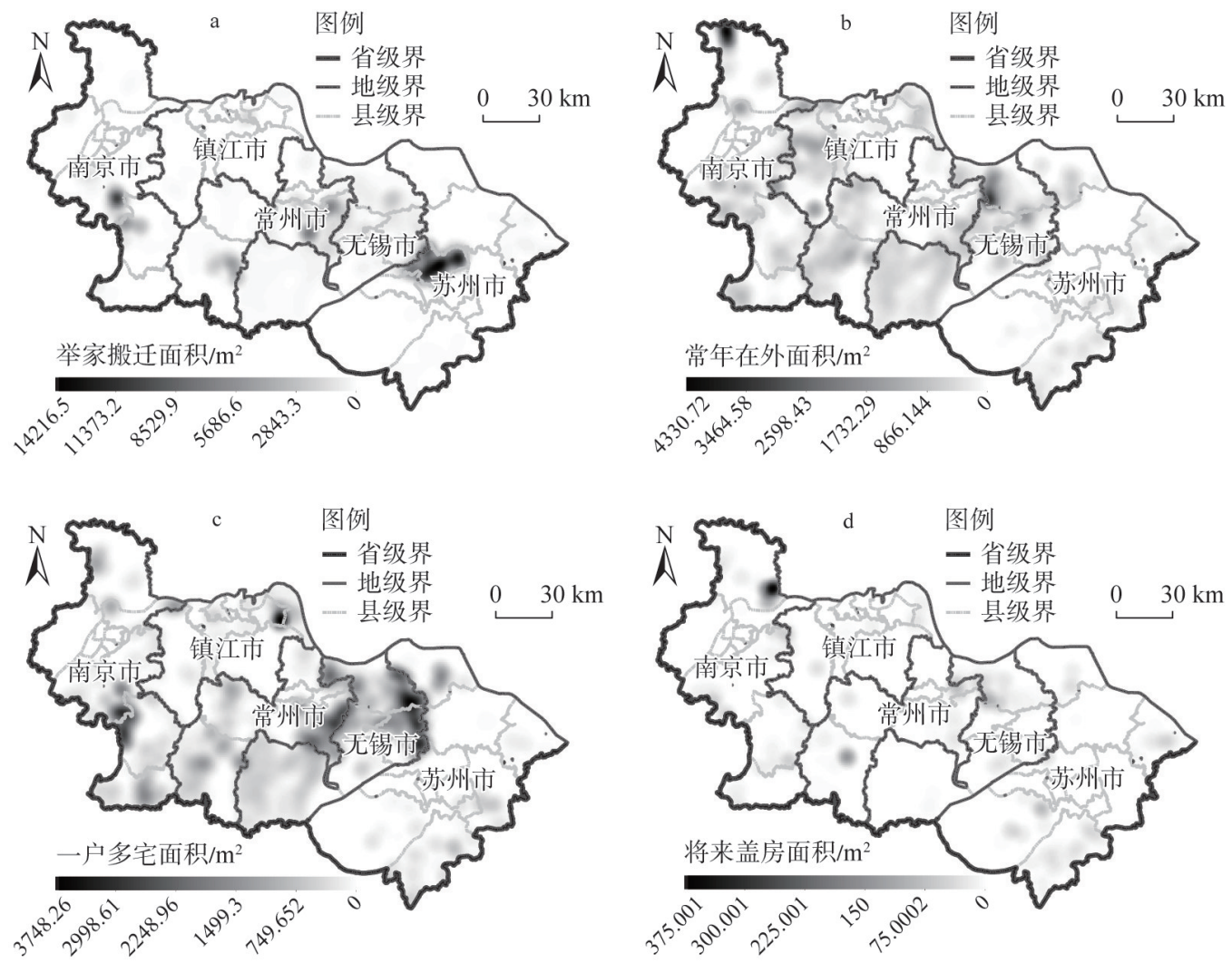

图 8 苏南地区农村样本宅基地空置原因分布

Fig. 8 Patterns of sample vacant housing land with different reasons in Southern Jiangsu 
弃的主要影响因素也具有与空置原因相类 似的自然决定痕迹, 在参与调查的废弃宅 基地中因为迁走而废弃的主要集中在自然 条件相对较差的生态敏感区，而另建新宅 类的废弃则以平原水网密集的经济发达区 为主。

\section{4 结论与讨论}

\section{1 结论}

土地利用问题的本质是经济社会快速 发展对土地利用的增长需求与限制土地利 用有效供给的生态、经济、社会诸要素间

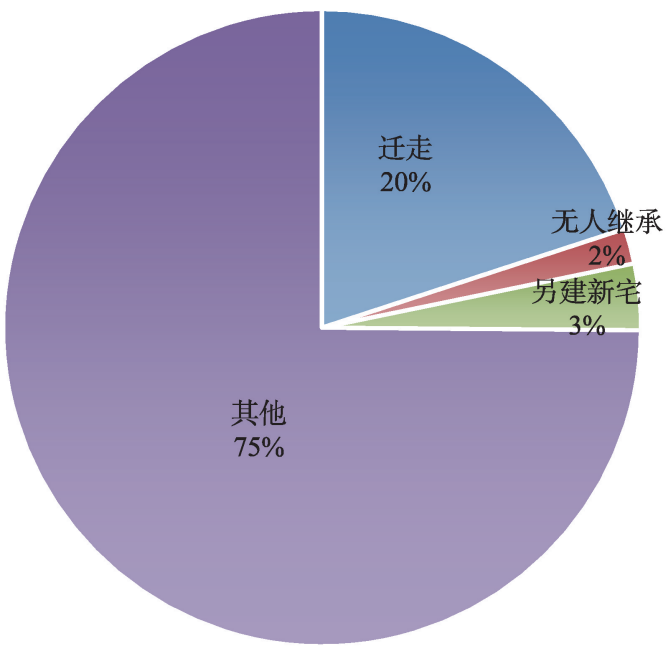
存在的矛盾关系 ${ }^{[46]}$ 。根据调查，苏南五市 有超过 10\%的农村宅基地处于空置或废弃 状态，“房子不用来住” 的问题在苏南农村 地区同样存在。一方面, 由于农村宅基地

图9 苏南地区农村样本宅基地废弃原因

Fig. 9 Abandoned reasons for sample rural housing land in Southern Jiangsu 使用中普遍存在“建新不拆旧”的现象， 因此建筑年代越久远的宅基地空废比例越高。另一方面，随着农村居民收人水平的持续 增加，农村新建住房的需求也不断增长，但是在宅基地功能由“居住保障” 向 “财产福 利” 转型的过程中, 有相当部分的农村新建住宅不是为了满足居住的刚性需求, 而是出 于对乡村振兴背景下宅基地 “升值” 的理性预期，导致在农村地区出现了类似城市“炒 房” 的大规模宅基地空置。尤其是 2010 年以后新建宅基地的正常使用率不足 $90 \%$ ，其空 置比率达到了 1980 年以来的最高水平，标志着发端于城镇地区的“地产霸权” 正在向乡 村地区曼延。

在空间上，由于城镇辐射具有非常明显的距离衰减特征，因此新宅基地中越靠近城 镇的功能转型特征越明显; 而对于老宅基地而言，由于其面积相对较小且功能单一，在 远离城镇的偏远地区很难满足居民的多样化需求，因此空置率呈现出由 “两端” 向 “中 间” 递减的趋势。换言之，农村宅基地的功能转型具有非常明显的时空异质性，大城市 周边的宅基地功能转型主要受城镇化的辐射影响，而在偏远农区则更多是由于宅基地自 身空间局促或功能缺陷的倒逼。因此，需要制定差别化的宅基地管理制度，以更有效地 促进不同类型地区乡村的全面振兴 ${ }^{[4]}$ 。比如，在近郊乡村需严格限制人均宅基地标准， 积极探索有偿退出制度，加快农村空置和废弃宅基地盘活; 而在偏远乡村相对宽松的规 模限制和翻建政策，严控 “一户多宅” 和 “囤地” 等浪费行为，明确发展方向和功能定 位，吸引离乡人员返乡创业、兴业，提高农村建设用地综合利用效率。

理论上，在中国特殊的城乡二元制度背景下，农村宅基地利用状态的空间分异在一 定程度上颠覆了传统竞租模型所描绘的距离衰减规律，城镇化过程中不可预测的政策变 化和随之而来的潜在收益正变得越来越重要。对于靠近城镇的农村居民，他们更关注土 地资本化（征收）所带来的潜在收益; 而对于远离城镇的农村居民，他们则将宅基地视 为集体经济组织成员的身份认同，用以保证其长期福利。总之，在城乡要素资源加快流 
动和乡村振兴战略实施的宏观背景下，农村宅基地正经历由原来单一的居住功能向资产 福利、身份表征等功能转型的过程。

\section{2 讨论}

土地作为区域发展的最重要要素之一，其利用效率与状态的空间分异是关系城乡融 合及乡村地域可持续发展的关键。虽然农村宅基地的功能转型不可避免地带来利用状态 与效率的变化, 采用不同利用状态来定量表征农村宅基地的功能转型特征, 对于理解农 村宅基地的隐性转型有一定价值。但要更深人地揭示农村宅基地的转型过程，还需要进 一步综合宅基地的实际功能及产权人的处置动机，以完善相关理论假设；而且本文同时 选择地级市和县级行政单元进行缓冲区分析，可能会存在不同等级城镇化地区辐射作用 的重叠嵌套, 需要在未来研究中考虑分割不同尺度和等级的影响。另外, 本文基于苏南 发达地区提出了农村宅基地转型的一般假设, 其适用性与科学性仍需在更大时空尺度下 检验。尤其在乡村振兴背景下，在尚未经历快速城镇化与工业化的传统农区，农村宅基 地的功能转型可能会有不同的空间路径，需要在后续研究中进行比较分析。

\section{参考文献(References):}

[1] LIU Y S, FANG F, LI Y H. Key issues of land use in China and implications for policy making. Land Use Policy, 2014, 40: 6-12.

[2] 龙花楼, 屠爽爽. 论乡村重构. 地理学报, 2017, 72(4): 563-576. [LONG H L, TU S S. Rural restructuring: Theory, approach and research prospect. Acta Geographica Sinica, 2017, 72(4): 563-576.]

[3] 刘彦随. 中国新时代城乡融合与乡村振兴. 地理学报, 2018, 73(4): 637-650. [LIU Y S. Research on the urban-rural integration and rural revitalization in the New Era in China. Acta Geographica Sinica, 2018, 73(4): 637-650.]

[4] 乔伟峰, 戈大专, 高金龙, 等. 江苏省乡村地域功能与振兴路径选择研究. 地理研究, 2019, 38(3): 522-534. [QIAO W F, GE D Z, GAO J L, et al. Detecting the pathways towards rural vitalization from the perspective of territorial functions in Jiangsu province. Geographical Research, 2019, 38(3): 522-534.]

[5] 李裕瑞, 卜长利, 曹智, 等. 面向乡村振兴战略的村庄分类方法与实证研究. 自然资源学报, 2020, 35(2): 243-256. [LI Y R, BU C L, CAO Z, et al. Village classification system for rural vitalization strategy: Method and empirical study. Journal of Natural Resources, 2020, 35(2): 243-256.]

[6] LIU Y S, LI Y H. Revitalize the world's countryside. Nature, 2017, 548(7667): 275-277.

[7] 胡智超, 彭建, 杜悦悦, 等. 基于供给侧结构性改革的空心村综合整治研究. 地理学报, 2016, 71(12): 2119-2128. [HU Z C, PENG J, DU Y Y, et al. Reconstructing hollow villages in the view of structural reform of the supply side. Acta Geographica Sinica, 2016, 71(12): 2119-2128.]

[8] LI Y R, LIU Y S, LONG H L, et al. Community-based rural residential land consolidation and allocation can help to revitalize hollowed villages in traditional agricultural areas of China: Evidence from Dancheng county, Henan province. Land Use Policy, 2014, 39: 188-198.

[9] ZHU F K, ZHANG F R, LI C, et al. Functional transition of the rural settlement: Analysis of land-use differentiation in a transect of Beijing, China. Habitat International, 2014, 41: 262-271.

[10] JIANG G H, HE X, QU Y B, et al. Functional evolution of rural housing land: A comparative analysis across four typical areas representing different stages of industrialization in China. Land Use Policy, 2016, 57: 645-654.

[11] 龙花楼. 中国农村宅基地转型的理论与证实. 地理学报, 2006, 61(10): 1093-1100. [LONG H L. Rural housing land transition in China: Theory and verification. Acta Geographica Sinica, 2006, 61(10): 1093-1100.]

[12] LI T T, LONG H L, LIU Y Q, et al. Multi-scale analysis of rural housing land transition under China's rapid urbanization: The case of Bohai Rim. Habitat International, 2015, 48: 227-238.

[13] 张佰林, 高江波, 高阳, 等. 中国山区农村土地利用转型解析. 地理学报, 2018, 73(3): 503-517. [ZHANG B L, GAO J B, GAO Y, et al. Land use transition of mountainous rural areas in China. Acta Geographica Sinica, 2018, 73(3): 503-517.] 
[14] LONG H L, HEILIG G K, LI X B, et al. Socio-economic development and land-use change: Analysis of rural housing land transition in the transect of the Yangtse River, China. Land Use Policy, 2007, 24(1): 141-153.

[15] 龙花楼, 李婷婷. 中国耕地和农村宅基地利用转型耦合分析. 地理学报, 2012, 67(2): 201-210. [LONG H L, LI T T. Analysis of the coupling of farmland and rural housing land transition in China. Acta Geographica Sinica, 2012, 67(2): 201-210.]

[16] 曲衍波, 姜广辉, 张佰林, 等. 山东省农村居民点转型的空间特征及其经济梯度分异. 地理学报, 2017, 72(10): 18451858. [QU Y B, JIANG G H, ZHANG B L, et al. Spatial characteristics of rural residential land transition and its economic gradient differentiation. Acta Geographica Sinica, 2017, 72(10): 1845-1858.]

[17] SONG W, CHEN B M, ZHANG Y, et al. Establishment of rural housing land standard in China. Chinese Geographical Science, 2012, 22(4): 483-495.

[18] RINDFUSS R R, WALSH S J, TURNER B L, et al. Developing a science of land change: Challenges and methodological issues. PNAS, 2004, 101(39): 13976-13981.

[19] HOLMES J, ARGENT N. Rural transitions in the Nambucca valley: Socio-demographic change in a disadvantaged rural locale. Journal of Rural Studies, 2016, 48: 129-142.

[20] MA W Q, JIANG G H, WANG D Q, et al. Rural settlements transition (RST) in a suburban area of metropolis: Internal structure perspectives. Science of the Total Environment, 2018, 615: 672-680.

[21] WEGREN S K, O'BRIEN D J, PATSIORKOVSKY V V. The economics of rural households in Russia: Impact of village location. Eurasian Geography and Economics, 2008, 49(2): 200-214.

[22] LONG H L, ZOU J, PYKETT J, et al. Analysis of rural transformation development in China since the turn of the New Millennium. Applied Geography, 2011, 31(3): 1094-1105.

[23] QU Y B, JIANG G G, ZHAO Q L, et al. Geographic identification, spatial differentiation, and formation mechanism of multifunction of rural settlements: A case study of 804 typical villages in Shandong province, China. Journal of Cleaner Production, 2017, 166: 1202-1215.

[24] 龙花楼. 论土地利用转型与乡村转型发展. 地理科学进展, 2012, 31(2):131-138. [LONG H L. Land use transition and rural transformation development. Progress in Geography, 2012, 31(2): 131-138.]

[25] 刘彦随, 刘玉. 中国农村空心化问题研究的进展与展望. 地理研究, 2010, 29(1): 35-42. [LIU Y S, LIU Y. Progress and prospect on the study of rural hollowing in China. Geographical Research, 2010, 29(1): 35-42.]

[26] 房艳刚, 刘继生. 基于多功能理论的中国乡村发展多元化探讨: 超越“现代化”发展范式. 地理学报, 2015, 70(2): 257-270. [FANG Y G, LIU J S. Diversified agriculture and rural development in China based on multifunction theory: Beyond modernization paradigm. Acta Geographica Sinica, 2015, 70(2): 257-270.]

[27] ZHU J M. Transition of villages during urbanization as collective communities: A case study of Kunshan, China. Cities, 2018, 72: 320-328.

[28] LIN G C S. State policy and spatial restructuring in post-reform China, 1978-1995. International Journal of Urban and Regional Research, 1999, 23(4): 670-696.

[29] 刘彦随, 鲁奇. 苏南现代化进程中的土地问题及对策. 地理科学进展, 1998, 17(2): 80-85. [LIU Y S, LU Q. Problem and countmeasure of land in themodernization processof Southern Jiangsu province. Progress in Geography, 1998, 17 (2): 80-85.]

[30] SARGESON S. Subduing "the rural house-building craze": Attitudes towards housing construction and land-use controls in four Zhejiang villages. The China Quarterly, 2002, 172: 927-955.

[31] 刘彦随, 刘玉, 翟荣新. 中国农村空心化的地理学研究与整治实践. 地理学报, 2009, 64(10): 1193-1202. [LIU Y S, LIU Y, ZHAI R X. Geographical research and optimizing practice of rural hollowing in China. Acta Geographica Sinica, 2009, 64(10): 1193-1202.]

[32] 龙花楼. 论土地整治与乡村空间重构. 地理学报, 2013, 68(8): 1019-1028. [LONG H L. Land consolidation and rural spatial restructuring. Acta Geographica Sinica, 2013, 68(8): 1019-1028.]

[33] 王亚辉, 李秀彬, 辛良杰, 等. 中国土地流转的区域差异及其影响因素: 基于 2003-2013年农村固定观察点数据. 地 理学报, 2018, 73(3): 487-502. [WANG Y H, LI X B, XIN L J, et al. Regional differences of land circulation in China and its drivers: Based on 2003-2013 rural fixed observation points data. Acta Geographica Sinica, 2018, 73(3): 487-502.] 
[34] 龙花楼, 李裕瑞, 刘彦随. 中国空心化村庄演化特征及其动力机制. 地理学报, 2009, 64(10): 1203-1213. [LONG H L, LI Y R, LIU Y S. Analysis of evolutive characteristics and their driving mechanism of hollowing villages in China. Acta Geographica Sinica, 2009, 64(10): 1203-1213.]

[35] 贺雪峰. 农村: 中国现代化的稳定器与蓄水池. 党政干部参考, 2011, (6):18-19. [HE X F. Countryside: Stabilizer and reservoir for China's mordenization. Chinese Cadres Reference, 2011, (6): 18-19.]

[36] XU W. The changing dynamics of land-use change in rural China: A case study of Yuhang, Zhejiang province. Environment and Planning A, 2004, 36(9): 1595-1615.

[37] ZHOU T, JIANG G H, ZHANG R J, et al. Addressing the rural in situ urbanization (RISU) in the Beijing-Tianjin-Hebei Region: Spatio-temporal pattern and driving mechanism. Cities, 2018, 75: 59-71.

[38] ZHANG M, WU W P, ZHONG W J, et al. The reshaping of social relations: Resettled rural residents in Zhenjiang, China. Cities, 2017, 60: 495-503.

[39] 李红波, 张小林, 吴启焰, 等. 发达地区乡村聚落空间重构的特征与机理研究: 以苏南为例. 自然资源学报, 2015, 30 (4): 591-603. [LI H B, ZHANG X L, WU Q Y, et al. Characteristics and mechanism of rural settlements spatial reconstruction in developed areas: A case study of Southern Jiangsu. Journal of Natural Resources, 2015, 30(4): 591-603.]

[40] LIU Y S, WANG J Y, LONG H L. Analysis of arable land loss and its impact on rural sustainability in Southern Jiangsu province of China. Journal of Environmental Management, 2010, 91(3): 646-653.

[41] LONG H L, LIU Y S, WU X Q, et al. Spatio-temporal dynamic patterns of farmland and rural settlements in Su-XiChang Region: Implications for building a new countryside in Coastal China. Land Use Policy, 2009, 26(2): 322-333.

[42] VEECK G, PANNELL C W. Rural economic restructuring and farm household income in Jiangsu, People's Republic of China. Annals of the Association of American Geographers, 1989, 79(2): 275-292.

[43] 宋小青. 论土地利用转型的研究框架. 地理学报, 2017, 72(3): 471-487. [SONG X Q. Discussion on land use transition research framework. Acta Geographica Sinica, 2017, 72(3): 471-487.]

[44] 翁一峰, 吕斌, 鲁晓军. “产权关系”视角下的乡村空间发展探究: 以无锡市阳山镇为例. 城市规划, 2014, 38(10): 5158. [WENG Y F, LYU B, LU X J. Research on rural spatial development in the view of property right relationship: A case of Yangshan town, Wuxi city, Jiangsu province. City Planning Review, 2014, 38(10): 51-58.]

[45] LI P X, GAO J L, CHEN J L. Quantitative assessment of ecological stress of construction lands by quantity and location: Case study in Southern Jiangsu, Eastern China. Environment, Development and Sustainability, 2020, 22: 1559-1578.

[46] 刘彦随, 陈百明. 中国可持续发展问题与土地利用/覆被变化研究. 地理研究, 2002, 21(3): 324-330. [LIU Y S, CHEN B M. The study framework of land use/cover change based on sustainable development in China. Geographical Research, 2002, 21(3): 324-330.]

[47] 龙花楼, 李秀彬. 长江沿线样带农村宅基地转型. 地理学报, 2005, 60(2): 179-188. [LONG H L, LI X B. Rural housing land transition in transect of Yangtze River. Acta Geographica Sinica, 2005, 60(2): 179-188.] 


\title{
Transition of rural housing land in Southern Jiangsu, China: Evidences from the utilization status perspective
}

\author{
GAO Jin-long ${ }^{1,2}$, LIU Yan-sui ${ }^{1}$, CHEN Jiang-long ${ }^{2,3}$ \\ (1. Institute of Geographic Sciences and Natural Resources Research, CAS, Beijing 100101, China; \\ 2. Key Laboratory of Watershed Geographic Sciences, Nanjing Institute of Geography and Limnology, CAS, \\ Nanjing 210008, China; 3. Collaborative Innovation Center of Modern Agriculture and Environmental \\ Protection in Jiangsu Province, Huai'an 223300, Jiangsu, China)
}

\begin{abstract}
Rural housing land transition is one of the most important aspects of land use transition, which has attracted interest among a wide variety of researchers as well as the government officials. To date, the majority of literatures in this field focuses mainly on the decline of rural housing land in respect of its share in the growth of total construction land with the development of local economy, while little attention has been paid to the change of its recessive morphology. Taking Southern Jiangsu, one of the most developed regions in China, as an example, this paper demystifies the general trajectory of the functional transformation of rural housing land through the lens of utilization status (i.e., normal, vacant, and abandoned). The results imply primarily that the issue of "housing is not for accommodation", which has been widely witnessed in urban China, has also been detected in rural areas of Southern Jiangsu. And a temporal and spatial heterogeneity of vacant and abandoned rural housing lands has been verified. Specifically, the transition of rural housing lands used before the 1980s tends to be more visible in the "both ends" near and far from the city with a relatively low share of vacant and abandoned lands to the total rural housing land in the central area. Within the double processes of urbanization and industrialization, the pattern of rural housing land transition during the last two decades of the 20th century shifts from the inverted-U trend to an inverted-S one, which is resulted from the distance attenuation of urban effects. With the functional transition of rural housing land from residence to property, the relationship between the utilization status of rural housing land and its location, particularly within the context of rural revitalization, has weakened in recent years. However, the share of vacant housing land has rebounded with a phenomenon of "housing land hoarding" being witnessed in rural areas since 2010, which predicts the sprawl of "real estate hegemony" originating in urban areas to rural areas.
\end{abstract}

Keywords: land use transition; rural housing land; vacant/abandoned land; rural revitalization; Southern Jiangsu 